\title{
Responses of Subtropical and Tropical Fruit Trees to Flooding in Calcareous Soil
}

\author{
Bruce Schaffer ${ }^{1}$ \\ Tropical Research and Education Center, University of Florida, 18905 S.W. $280^{\text {th }}$ Street, Homestead, FL 33031 \\ Frederick S. Davies \\ Department of Horticultural Sciences, P.O. Box110690, University of Florida, Gainesville, FL 32611 \\ Jonathan H. Crane \\ Tropical Research and Education Center, University of Florida, 18905 S.W. $280^{\text {th }}$ Street, Homestead, FL 33031
}

\begin{abstract}
Additional index words. avocado, Persea americana, mango, Mangifera indica, Annona, pond apple, Annona glabra, carambola, Averrhoa carambola, net $\mathrm{CO}_{2}$ assimilation, mineral nutrition, hypertrophied stem lenticels

Abstract. The effects of flooding calcareous soil on physiology and growth have been studied for several subtropical and tropical fruit crops including avocado (Persea americana Mill.), mango (Mangifera indica L.), carambola (Averrhoa carambola L.), and several Annona species. In calcareous soils that have a high pH, short-term flooding can actually be beneficial to subtropical and tropical fruit crops by increasing the solubility of particle-bound nutrient elements such as $\mathrm{Fe}, \mathrm{Mn}$ and $\mathrm{Mg}$ due to flooding-induced decreases in soil $\mathrm{pH}$. Additionally, flooding reduces the redox potential in the soil, resulting in $\mathrm{Fe}$ being reduced from $\mathrm{Fe}^{3+}$ to $\mathrm{Fe}^{2+}$, which is the cation metabolized by plants. As with other woody perennial crops, one of the early physiological responses of subtropical and tropical fruit trees to flooding is a decrease in stomatal conductance and net $\mathrm{CO}_{2}$ assimilation. If the flooding period is prolonged, lack of $\mathrm{O}_{2}$ (anoxia) in the soil results in a reduction of root and shoot growth, wilting, decreased nutrient uptake and eventual death. The flooding duration required to cause tree mortality varies among species, among cultivars within species, and with environmental conditions, particularly temperature. Several tropical and subtropical fruit crops have anatomical or morphological adaptations to tolerate prolonged flooding, such as development of hypertrophied stem lenticels, adventitious rooting or formation of porous aerenchyma tissue. For grafted trees, flooding-tolerance is conferred by the rootstock and not the scion. Therefore there is a possibility to increase flood tolerance of subtropical and tropical fruit crops by identifying or developing flood-tolerant rootstocks.
\end{abstract}

In many parts of the world, subtropical and tropical fruit production occurs in areas with poorly drained soils, or in areas that are prone to cyclical flooding. For example, in southern Florida, recent efforts to revitalize the flora and fauna of the Everglades National Park have increased water flow, resulting in an elevated water table in the park and surrounding agricultural areas. Additionally many areas where subtropical and tropical fruit are grown are frequently exposed to catastrophic flooding as the result of tropical storms or hurricanes. There are two reviews of fruit crops and flooding (Rowe and Beardsell, 1973; Schaffer et al., 1992). However, recently there have been several additional studies on the effects of flooding on fruit crops, including subtropical and tropical fruit trees.

Flooding detrimentally affects many subtropical and tropical fruit crops including avocado (Ploetz and Schaffer, 1987; 1989; Schaffer and Ploetz, 1989), mango (Larson et al., 1991b, 1991c, 1992, 1993a, 1993b; Schaffer et al., 1994), carambola (Joyner and Schaffer, 1989; Marler et al, 1994), citrus (Phung and Knipling, 1976; Schaffer, 1991; Schaffer and Moon, 1990; Syvertsen et al., 1983) and commercial Annona (George et al., 1987; Nuñez-Elisea et al., 1999; Samson, 1980). The primary effect of flooding on crop physiology and growth results from the depletion of soil oxygen (Larson et al., 1991a; Ponnamperuma, 1972, 1984; Schaffer et al., 1992). The earliest detectable physiological symptoms of flooding

\footnotetext{
${ }^{1}$ To whom reprint requests should be address; e-mail bas@ifas.ufl.edu.
}

stress include decreased net $\mathrm{CO}_{2}$ assimilation, stomatal conductance, and transpiration (Schaffer et al., 1992). Therefore, measuring leaf gas exchange characteristics is useful for determining the degree of flooding stress before any visible signs of stress (Schaffer et al., 1992). Prolonged flooding usually results in a cessation of root and shoot growth, wilting, decreased nutrient uptake, and often tree death (Crane and Davies, 1989; Schaffer et al., 1992). It also decreases flowering, fruit set, yield and fruit quality of several fruit crops (Rowe and Beardsell, 1973; Schaffer et al., 1992). However, some tropical fruit crops, such as carambola (Joyner and Schaffer, 1989), can adapt to cyclical flooding. In fact, short-term flooding can actually stimulate flowering of some fruit crop species (Schaffer et al., 1992). Tolerance of fruit crops to waterlogged conditions is mainly determined by the rootstock and not the scion (Rowe and Beardsell, 1973; Schaffer et al., 1992). Thus, the potential may exist to increase flood-tolerance of some tropical fruit tree species by the use of flood-tolerant rootstocks (Schaffer, 1998).

In many subtropical and tropical fruit production areas, including south Florida (Noble et al., 1996), the Virgin Islands (Martinez et al., 1998), and areas of Puerto Rico (USDANRCS, 2004), subtropical and tropical fruit crops are grown in calcareous soils that have a high $\mathrm{pH}$ due to large amounts of calcium carbonate (limestone). Within the Caribbean region and Latin America alone, such soils account for as much as 18 percent of the soil types (FAO-AGL, 2004). There are some aspects of flooding related to soil chemistry that are unique to calcareous soils. These are generally related to availability of micronutrients, particularly $\mathrm{Fe}$ in these high $\mathrm{pH}$ soils (Larson et al., 1991a, 1992). In nonflooded calcareous soils, much of the Fe, an essential element for plant growth and development, is unavailable for plant uptake because it is tightly bound to soil particles or precipitated as water-insoluble iron hydroxide (Mengel and Kirkby, 1982). At times, most subtropical and tropical fruit tree species in calcareous soils exhibit signs typical ofFe deficiency, characterized by an interveinel yellowing of young leaves. This characteristic Fe deficiency symptom, called iron chlorosis (Lucena, 2000), is so prevalent in calcareous soils that it is commonly called "lime-induced chlorosis" (Mengel and Geurtzen, 1988). In soil, most $\mathrm{Fe}$ is present in the ferric $\left(\mathrm{Fe}^{3+}\right)$ form. However, $\mathrm{Fe}$ is absorbed by plant roots as either $\mathrm{Fe}^{2+}$ or Fe chelates. Also, plants utilize $\mathrm{Fe}$ in the ferrous $\left(\mathrm{Fe}^{2+}\right)$ form (Marchner and Römheld, 1994). Thus, $\mathrm{Fe}^{3+}$ must be reduced to $\mathrm{Fe}^{2+}$ at the roots for plants to absorb and metabolize it (Brown, 1978; Chaney et al., 1972). A reduction of iron from $\mathrm{Fe}^{3+}$ to $\mathrm{Fe}^{2+}$ that is catalyzed by the enzyme ferric chelate reductase takes place in the roots (Mengel, 1994). Flooding reduces $\mathrm{Fe}^{3+}$ in calcareous soil to $\mathrm{Fe}^{2+}$ (Larson et al., 1991a), the form that is metabolized by plants.

An understanding of the effects of flooding on the physiology and growth of subtropical and tropical fruit crops in calcareous soils may aid in selection of cultivars adapted to flood-prone or poorly drained soils, or suggest cultural methods to improve flood tolerance and increase the agricultural potential of flood- 
prone areas with limited negative impact on the environment. During the past 20 years, research has been conducted on the effects of flooding on select tropical and subtropical fruit tree species cultivated in calcareous soils, including avocado (Ploetz and Schaffer, 1987, 1989; Schaffer and Ploetz, 1989, Schaffer and Whiley 2002, 2003; Whiley and Schaffer, 1994), mango (Larson et al., 1991a, 1991b; Schaffer et al., 1994), 'Tahiti' lime (Schaffer, 1991; Schaffer and Moon, 1990), carambola (Joyner and Schaffer, 1989), and several species of Annona (Núñez-Elisea et al., 1998, 1999; Ojeda et al., 2004a, 2004b). This review will outline the current state of knowledge of the effects of flooding, particularly in calcareous soil, on the physiology and growth of some of these subtropical fruit tree species and adaptations that some of these species exhibit that enables them to tolerate flooding in calcareous soils.

\section{RESPONSES OF AVOCADO TREES TO FLOODING}

Avocado is considered a flood-sensitive species with physiological responses occurring shortly after soils become waterlogged (Schaffer et al., 1992). In flooded soils, the decline in net $\mathrm{CO}_{2}$ assimilation is generally accompanied by decreases in stomatal conductance and intercellular partial pressure of $\mathrm{CO}_{2}$ in the leaves (Ploetzand Schaffer, 1989; Schaffer and Ploetz, 1989). However, the temporal separation between these physiological events has not been defined, which would be useful for determining if flood-induced reductions in photosynthesis in avocado are due to stomatal or nonstomatal factors (Schaffer et al., 1992).

For avocado trees flooded in calcareous soil, net $\mathrm{CO}_{2}$ assimilation declined linearly after trees were flooded, with a mean net $\mathrm{CO}_{2}$ assimilation of zero $30 \mathrm{~d}$ after trees were flooded. However, the effects of flooding on avocado are greatly exacerbated by phytophthora root rot caused by the oomycete, Phytophthora cinnamomi (Ploetz and Schaffer, 1987, 1989; Schaffer et al., 1992; Schaffer and Whiley; 2002; Whiley and Schaffer, 1994). For avocado trees in calcareous soil, preinoculated with Phytophthora cinnamomi, net $\mathrm{CO}_{2}$ assimilation declined to zero within 1 week after trees were flooded (Ploetz and Schaffer, 1989). All flooded trees died within 2 weeks of continuous flooding. In another study of trees in calcareous soils in containers, $25 \%$ to $30 \%$ root necrosis from preinoculating plants with phytophthora root rot resulted in almost a complete inhibition of photosynthesis after soils were flooded for one week (Fig. 1). However, in the same soil, nonflooded trees were able to sustain up to $90 \%$ root necrosis with only a $65 \%$ decrease in net $\mathrm{CO}_{2}$ assimilation (Schaffer and Ploetz, 1989; Schaffer et al., 1992; Schaffer and Whiley, 2002; Whiley and Schaffer, 1994). The synergistic relationship between flooding and phytophthora root rot of avocado in calcareous soils indicates that flooding-induced stress to avocado trees may be reduced by controlling phytophthora root rot (Schaffer and Whiley, 2003). In these soils, fungicides applied to the soil (metallaxyl) or injected into the tree (Fosetly-Al) were effective in preventing phytophthora root rot of avocado (Schaffer et al., 1992). However, this is not a practical solution because in nonflooded conditions trees can tolerate a large amount of root necrosis from phytophthora root rot and growers probably would not want to bear the cost of applying fungicides in the event that flooding may or may not occur. Amore practical solution is the use of $P$. cinnamomi resistant rootstocks (Ploetz et al., 2002). However, there are no known Phytophothora-resistant Persea americana rootstocks adapted to calcareous soils (Witjaksono, 1997). Although some other species in the genus Persea are $P$. cinnamomi resistant, they are not sexually or graft compatible with avocado (Witjaksono, 1997). A possible solution for developing Phythophthora-resistant rootstocks is through molecular breeding. There has been limited success in somatic hybridization of Persea americana with the $P$. cinnamomi-resistant species, Persea borbonia, which is native to the calcareous soils of southern Florida (Litz et al., 2005, Witjaksono, 1997). Persea borbonia and Persea americana have been successfully hybridized by protoplast fusion, with resulting plantlets developed in tissue culture. However, this is at best a long-range solution because plants have yet to be screened for P. cinnamomi resistance and even resistant plants would need to be field-tested for several years to determine if they have characteristics immediate solution will be the development of $P$. cinnamomi-resistant selections through conventional breeding. There are currently some potentially promising phytophthora root rot-resistant rootstock selections that are adapted to calcareous soil (Ploetz et al, 2002, R.C. Ploetz, personal communication). suitable for horticultural production. A more

\section{RESPONSES OF MANGO TREES TO FLOODING}

Some of the first measured physiological responses to flooding of mango trees are reductions in net $\mathrm{CO}_{2}$ assimilation, stomatal conductance and transpiration, which can occur within 2 to $3 \mathrm{~d}$ after roots are submerged (Larson et al., 1991c, Schaffer et al., 1992). Removing trees from flooded conditions after $28 \mathrm{~d}$ reversed the flooding-induced decline in leaf gas exchange, resulting in a gradual increase in net $\mathrm{CO}_{2}$ assimilation, stomatal conductance and transpiration.

Although flooding adversely affects mango trees, short-term flooding of trees in limestone soils can result in increased micronutrient availability and improved plant nutritional status. In calcareous soils in which $\mathrm{Fe}$ was withheld from nutrient applications, short-term flooding (10 to $20 \mathrm{~d}$ ) of mango trees resulted in an increase in net $\mathrm{CO}_{2}$ assimilation to above preflooding levels following the release of trees from flooding (Larson et al., 1992). This increase in net $\mathrm{CO}_{2}$ assimilation has been correlated with improved Fe and Mn uptake as a result of these elements becoming more soluble when calcareous soils are flooded (Larson et al., 1991b, 1992).

Several studies with container-grown trees have indicated variable responses with respect to tree survival, which may be due to genetic variability among trees. Larson et al. (1991c) observed that as many as $45 \%$ of trees died after their roots were submerged in water for 4 to $10 \mathrm{~d}$, but in the surviving population no further mortality occurred when flooding was extended for up to $110 \mathrm{~d}$. In other experiments, there was no treemortality after container-grown mango trees were flooded from one to several months, although tree growth was significantly reduced (Larson et al., 1991c; Whiley and Schaffer, 1997).

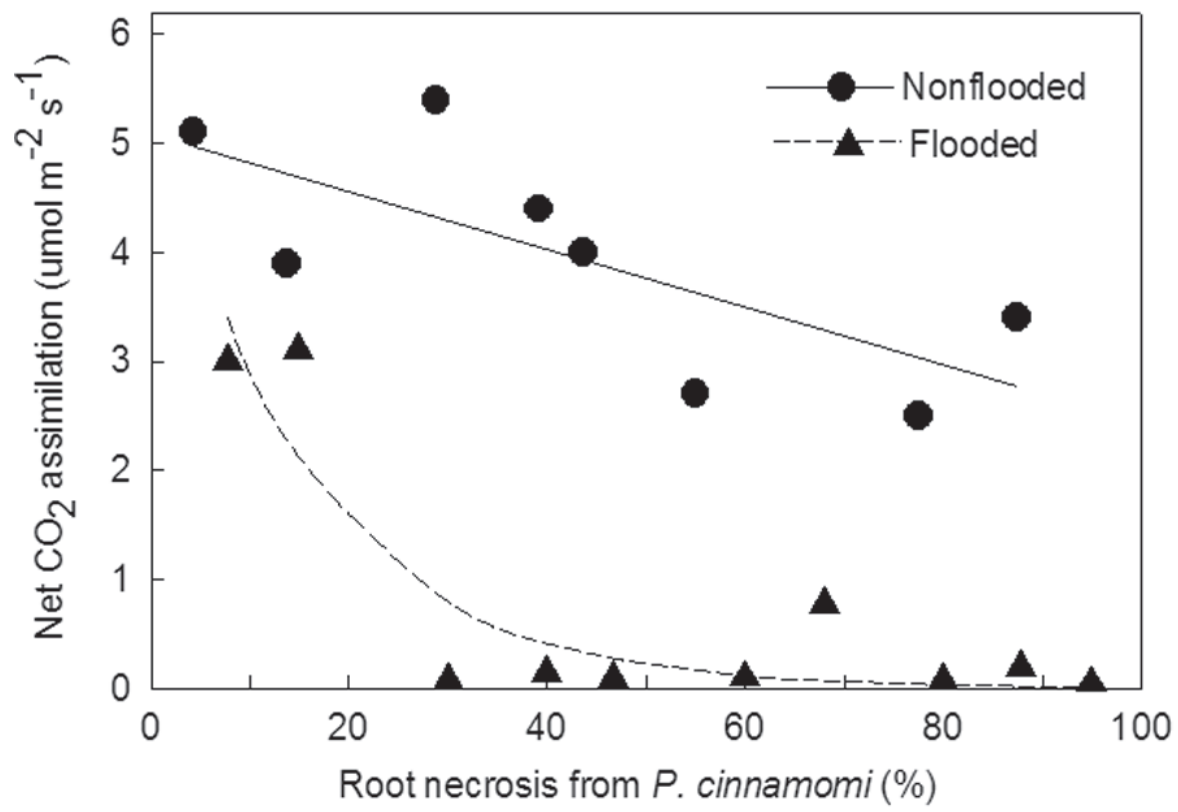

Fig. 1. Net $\mathrm{CO}_{2}$ assimilation (A) and percent root necrosis from phytophthora root rot for flooded (for 1 week) and nonflooded avocado trees. The regression line for flooded plants is $\mathrm{y}=5.6 \mathrm{e}^{-65 \mathrm{x}}, r^{2}=0.83$ and for nonflooded plants $\mathrm{y}=5.1-0.26 \mathrm{x}, r^{2}=0.53$ (From Schaffer and Ploetz, 1989). 
The ability of mango trees to survive prolonged flooding, as presumably often occurs during heavy monsoonal rains, appears to be dependent on the development of hypertrophic (swollen) stem lenticels (Fig. 2). The initial stages of lenticel hypertrophy are characterized by the development of intercellular spaces in the phellem tissue and production of additional phellem tissue by increased phellogen activity. Later stages of hypertrophy are characterized by the development of intercellular spaces in

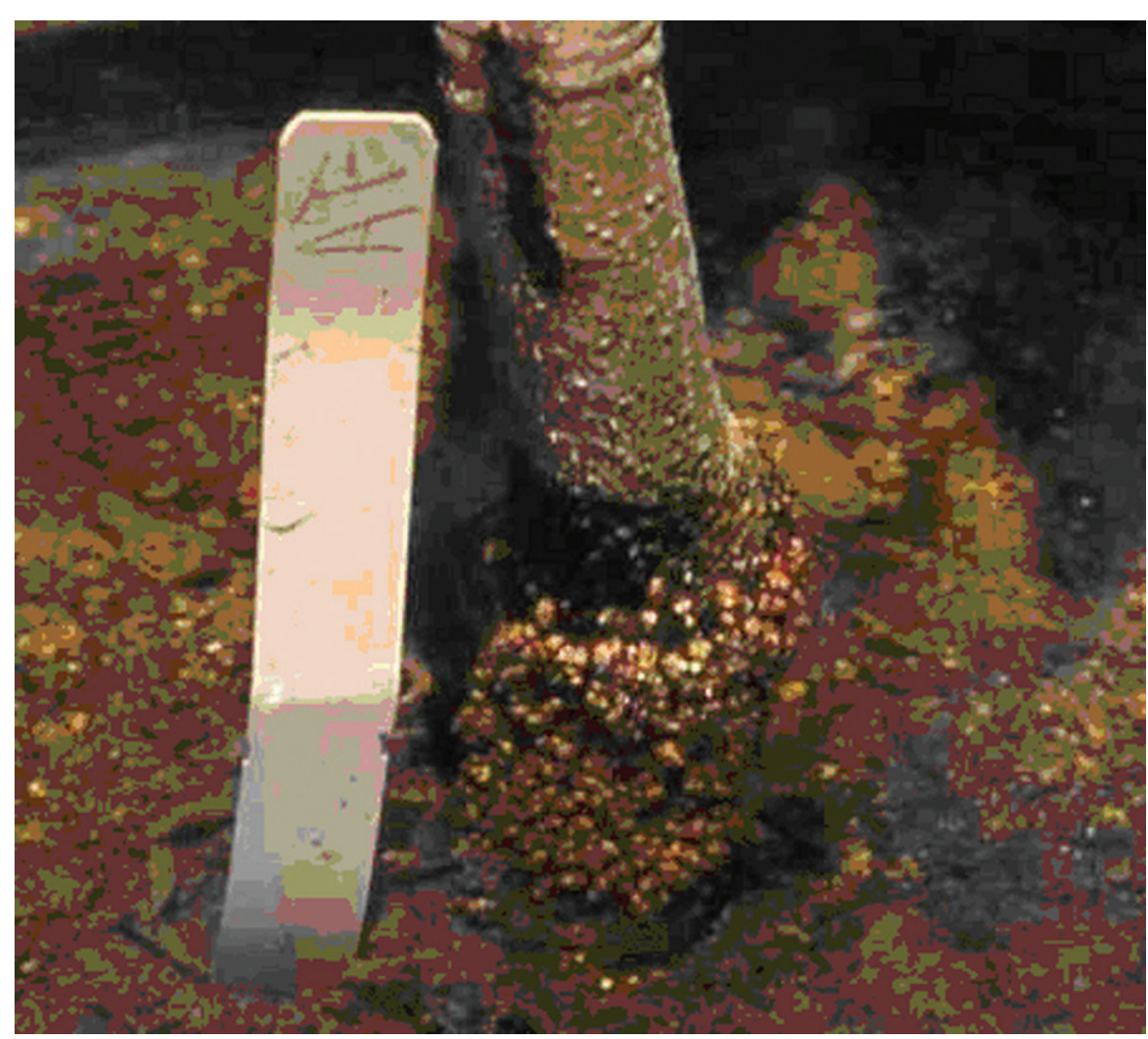

Fig. 2. Trunk of a flooded mango tree showing hypertrophied lenticels.

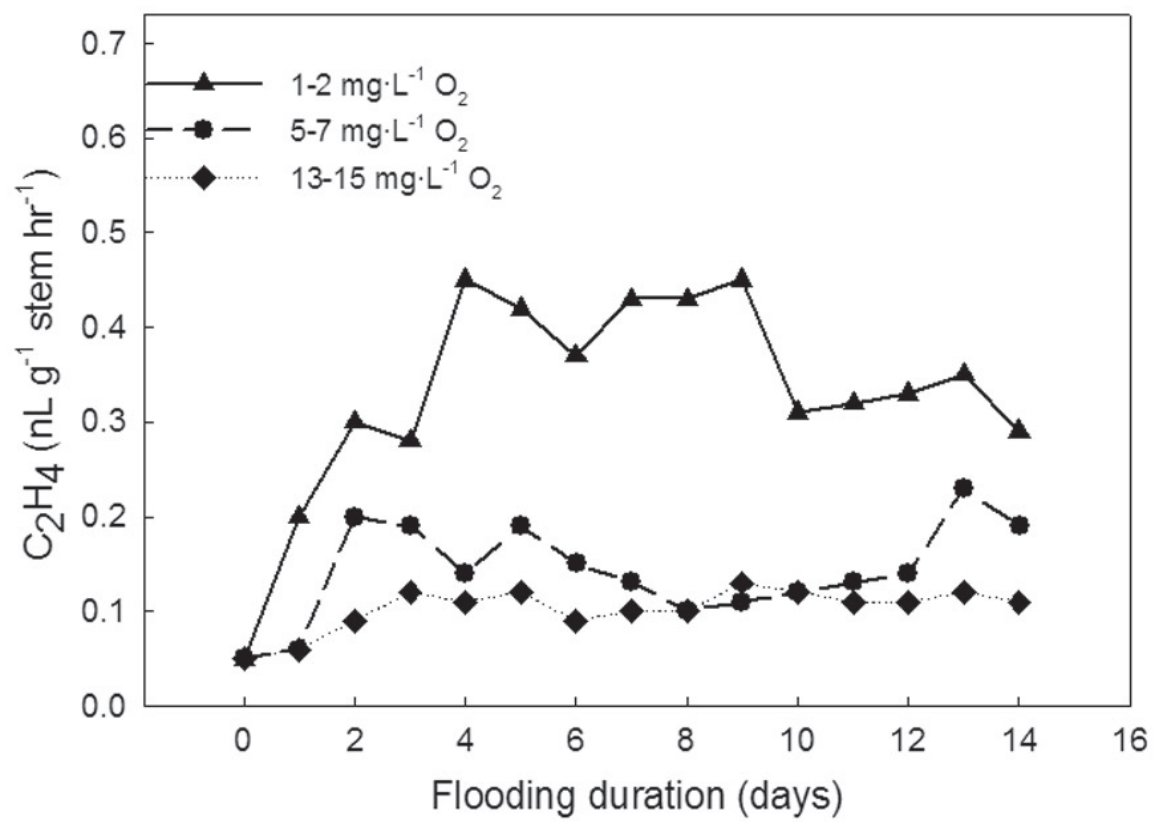

Fig. 3. Effect of $\mathrm{O}_{2}$ concentration in the flood water on ethylene evolution from hypertrophied stem lenticels of mango trees (From Larson et al., 1993a).

the phellem tissue and cortex (Larson et al., 1991d). Observations vary among studies as to whether or not trees developed hypertrophic lenticels or how quickly after flooding they form. In mango trees that died within a few days as a result of flooding there was no lenticel hypertrophy. However, for trees that survived flooding, stem lenticels hypertrophied within 10 d (Larson et al., 1991d, 1993a, 1993b). Sealing hypertrophied lenticels with petroleum jelly or silicone resulted in trees dying within

HortScience Vol. 41(3) June 2006
$3 \mathrm{~d}$ of flooding (whereas nonflooded controls sealed with the same substances survived), thereby demonstrating the importance of hypertrophic lenticels for tree survival. The role of hypertrophic lenticels in flood tolerance of mango is not clear, although they may serve as excretory sites for the elimination of potentially toxic compounds such as ethanol, acetaldehyde and ethylene which result from anaerobic metabolism in flooded roots (Larson et al., 1993a, 1993b; Whiley and Schaffer, 1997). In fact, when mango trees were grown hydroponically, ethylene concentration in the space around the stem lenticels was significantly higher when roots were submerged in water with 2 to $5 \mathrm{mg} \cdot \mathrm{L}^{-1} \mathrm{O}_{2}$ than 5 to $8 \mathrm{mg} \cdot \mathrm{L}^{-1} \mathrm{O}_{2}$ (Fig. 3; Larson et al., 1993a). Hypertrophic lenticels may also aid in conferring flood tolerance to mango by enhancing $\mathrm{O}_{2}$ diffusion to the roots (Whiley and Schaffer, 1997).

Hypertrophic lenticels can also develop on stems of very young mango trees subjected to flooded conditions (B. Schaffer, personal observations). Therefore, development of hypertrophied stem lenticels may be useful as a screening and selection tool for flood-tolerant mango cultivars. However, many mango cultivars are monoembyonic, producing one zygotic embryo and therefore do not come "true to seed" (Iyer and Degani, 1997). Therefore, once flood-tolerant, monoembryonic mango trees that form lenticels are identified, they must be clonally propagated. Monoembryonic mango cultivars have been clonally propagated through tissue culture techniques (Litz and Lavi, 1997), but to date long-term survival (more that a few months) of mango trees grown directly from tissue culture has not been achieved.

In some instances, adventitious roots have developed above the water line when containergrown mango trees were flooded for long periods (Schaffer et al., 1994). These roots may facilitate the absorption and translocation of $\mathrm{O}_{2}$ to submerged roots, and their development is a common morphological response of many woody plants to anoxia. The development of adventitious roots has not been reported for flooded, field-grown mango trees and adventitious roots may only form on young trees after extended flooding periods (longer than one week) which usually do not occur under normal production conditions (Whiley and Schaffer, 1997).

Vegetative growth of mango trees generally declines when trees become flooded for more that 2 to $3 \mathrm{~d}$. When mango trees growing in calcareous soil in containers were flooded for about $10 \mathrm{~d}$ there was a $57 \%$ reduction in shoot extension growth, whereas when trees were flooded for $>110 \mathrm{~d}$, there was a $94 \%$ reduction in shoot extension growth (Larson et al., 1991c). In a subsequent study, the stem radial growth (a more sensitive indicator of tree growth than shoot extension growth) of mango trees decreased 2 weeks after roots were submerged. Flooding for more than $14 \mathrm{~d}$ also reduced root dry weight that increased the shoot to root ratio (Larson et al., 1991c). These adverse effects of flooding on the growth of mango trees are expected as reduced net photosynthesis and 
presumably higher root respiration limit the availability of photoassimilates required for growth.

\section{RESPONSES OF ANNONA TREES TO FLOODING}

The genus Annona includes several commercial subtropical and tropical fruit tree species including sugar apple (Annona squamosa L.), cherimoya (A. cherimola Mill.), atemoya (A. squamosa $\times A$. cherimola) and $\operatorname{soursop}(A$. muricata L.) collectively commonly referred to as annonas (Nakasone and Paull, 1998). Commercial annona varieties are generally grown on seedling rootstocks (Popenoe, 1974). These trees are very susceptible to soil flooding (Popenoe, 1974) and root diseases prevalent in saturated soils. Flooding of commercial annona species, even for short periods, reduces net $\mathrm{CO}_{2}$ assimilation and vegetative growth (Nuñez-Elisea et al., 1999), may cause defoliation, and severely reduces flowering and fruit set (Marler et al., 1994).

Pond apple (A. glabra), native to subtropical and tropical America including southern
Florida, is of limited commercial value as a fruit crop (Popenoe, 1974). Unlike commercial Annona species, A. glabra is extremely flood tolerant and has even been referred to as "swamp-loving" (Popenoe, 1974; Zotz et al., 1997). Similar to some mango cultivars, flooded pond apple seedlings develop hypertrophied stem lenticels and also exhibit thicker stems with reduced xylem density as a result of flooding (Nuñez-Elisea et al., 1999).

Based on leaf gas exchange, growth and reproductive development measurements of continuously flooded, cyclically flooded and nonflooded trees, A. glabra seedling trees and rootstocks and $A$. muricata seedlings are relatively flood-tolerant (Nuñez-Elisea et al., 1997, 1998, 1999). However, many commercial Annona species, such as atemoya are not graft compatible with A. glabra. For example, 'Gefner' atemoya, the major Annona cultivar grown commercially in southern Florida, is not directly graft compatible with $A$. glabra rootstock. However, graft compatibility can be achieved with the use of interstocks that are compatible with both the scion and rootstock (Nuñez-Elisea et al., 1997, 1998, 1999). The

Table 1. Effects of flooding on percent budbreak, shoot length and number of leaves per shoot on seedling and grafted Annona trees. ${ }^{2}$

\begin{tabular}{lcccc}
\hline $\begin{array}{l}\text { Scion/ } \\
\text { rootstock }\end{array}$ & Treatment & $\begin{array}{c}\text { Budbreak } \\
(\%)\end{array}$ & $\begin{array}{c}\text { Shoot length } \\
(\mathrm{mm} \pm \mathrm{SD})\end{array}$ & $\begin{array}{c}\text { Leaves/shoot } \\
(\text { no. }) \pm \text { SD }\end{array}$ \\
\hline A. glabra seedling & $\begin{array}{c}\text { Nonflooded } \\
\text { Flooded }\end{array}$ & 40 & $126 \pm 32$ & $6.9 \pm 1.6$ \\
A. muricata seedling & $\begin{array}{c}\text { Nonflooded } \\
\text { Flooded }\end{array}$ & 40 & $120 \pm 28$ & $5.6 \pm 1.3$ \\
& 80 & $140 \pm 32$ & $9.0 \pm 2.1$ \\
A. squamosa seedling & Nonflooded & 65 & $68 \pm 19$ & $7.1 \pm 1.8$ \\
& Flooded & 60 & $53 \pm 11$ & $4.3 \pm 0.9$ \\
49-11/A. glabra & Nonflooded & 10 & $19 \pm 6$ & $4.5 \pm 1.0$ \\
& Flooded & 50 & $47 \pm 12$ & $4.7 \pm 1.1$ \\
49-11/A. reticulata & & 65 & $180 \pm 34$ & $8.8 \pm 1.9$ \\
& Nonflooded & 50 & $96 \pm 17$ & $6.6 \pm 1.5$ \\
& Flooded & 19 & $5 \pm 2$ & $1.3 \pm 0.4$ \\
\hline
\end{tabular}

${ }^{2}$ From: Nuñez-Elisea et al., 1997.

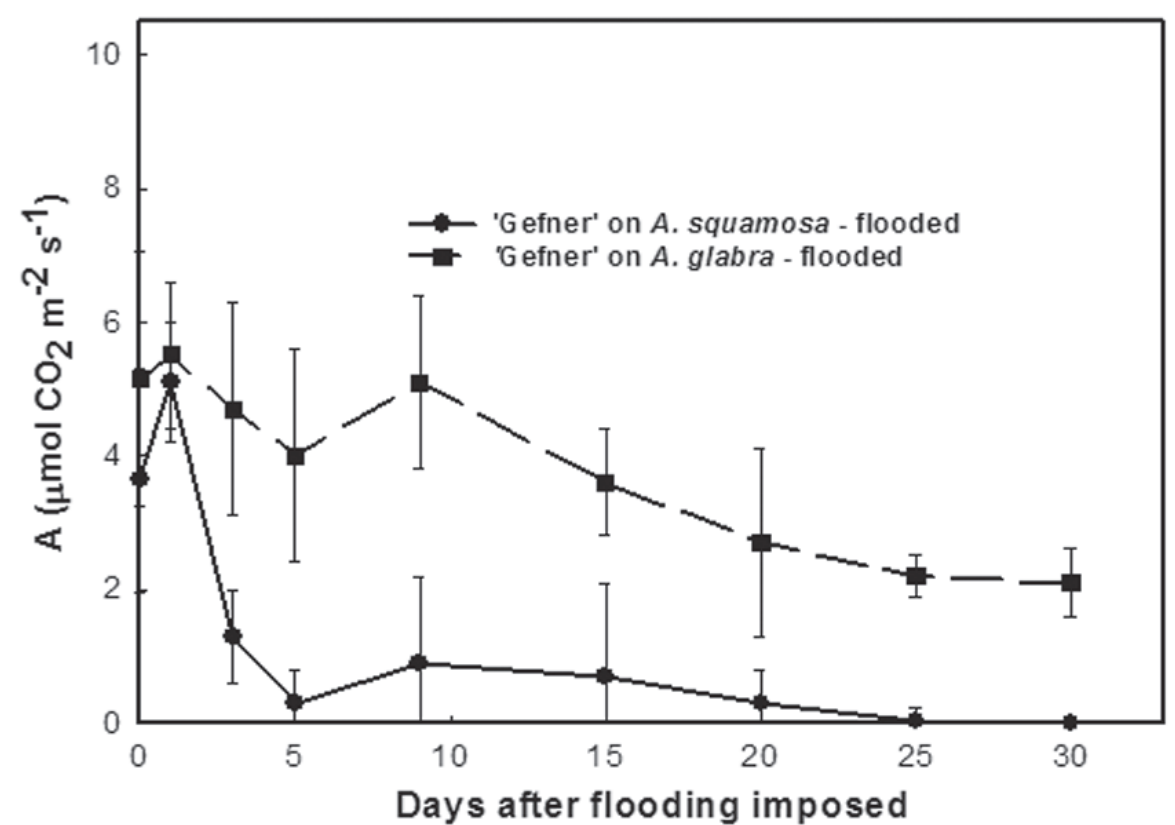

Fig. 4. Effect of flooding on net $\mathrm{CO}_{2}$ assimilation (A) of Annona squamosa and Annona glabra (from Ojeda et al., 2004b). annona selection. '49-11', a 'Gefner' atemoya $\times$ A. reticulata hybrid (Zill's High Peformance Plants, Boynton Beach, Fla.) has proven to be a good interstock for this purpose (NuñezElisea et al., 1997, 1998) and there are other interstocks currently being evaluated (G. Zill, personal communication). In glasshouse studies, flooding did not significantly reduce the percentage of budbreak, the mean shoot length, or the number of leaves per shoot of A. glabra and A. muricata seedlings compared with nonflooded control plants (Table 1). However, flooding significantly reduced the percentage of budbreak, mean shoot length, and the number of leaves per shoot of $A$. squamosa and $A$. reticulata seedlings, which are traditionally used as Annona rootstocks. Additionally, flooding scions of '49-11' grafted onto A. glabra seedlings resulted in an increase in the percentage of budbreak, mean shoot length and number of leaves per shoot (Table 1). 'Gefner' atemoya can be successfully grafted onto A. glabra using ' $49-11$ ' as an interstock. The resulting scion-interstock-rootstock combination is extremely flood-tolerant or flood adapted (Nuñez-Elisea et al., 1999). After several weeks of continuous flooding, net $\mathrm{CO}_{2}$ assimilation of 'Gefner'/49-11/A. glabra was not significantly reduced compared with that of nonflooded trees, whereas flooding significantly reduced net $\mathrm{CO}_{2}$ assimilation of 'Gefner' on A. squamosa rootstock (Fig. 4).

Field experiments in Homestead, Fla., and the U.S. Virgin Islands have indicated that in nonflooded, calcareous soils with high $\mathrm{pH}(\mathrm{pH}$ > 7.2) A. glabra seedlings and commercial Annona species grafted onto $A$. glabra rootstock are prone to Fe deficiency (Fig. 5) and require soil applications of considerably more chelated Fe than traditional Annona rootstocks, unless the soil is periodically flooded (B. Schaffer, unpublished data). However, when aerated alkaline soils are flooded, $\mathrm{Fe}$ becomes more soluble (Fig. 6; Larson et al., 1991a) and more readily available for plant uptake. Additionally, under anaerobic conditions in flooded soil, Fe, in the form of $\mathrm{Fe}^{3+}$, is reduced to $\mathrm{Fe}^{2+}$, which is more available to the plant (Ponnamperuma, 1972, 1984). For two southern Florida soils, Chekika and Krome very gravelly loam, 7 weeks of continuous flooding resulted in 15 to 30 times more $\mathrm{NH}_{4} \mathrm{OAc}$ extractable $\mathrm{Fe}$ than the same soils that were not flooded (Larson et al., 1991a). In another study, Fe uptake by mango trees in Krome very gravelly loam was significantly greater for flooded plants than for plants grown in nonflooded soil (Fig. 7; Larson et al., 1992). In its natural habitat, A. glabra is subjected to periodic flooding, which presumably ensures adequate $\mathrm{Fe}$ for the plant. However, if this species is to be used as a rootstock, the interaction between flooding and $\mathrm{Fe}$ availability and the Fe requirements in flooded and nonflooded soils must be determined.

As mentioned previously, most Fe in soil is present as $\mathrm{Fe}^{3+}$, which must be reduced to $\mathrm{Fe}^{2+}$ for plants to metabolize it (Brown, 1978; Chaney et al., 1972; Marchner and Römheld, 1994). The reduction of $\mathrm{Fe}^{3+}$ to $\mathrm{Fe}^{2+}$ is cata- 
lyzed by the enzyme, ferric chelate reductase (Mengel, 1994). In nonflooded calcareous soils, the much higher requirements of $\mathrm{Fe}$ fertilizer for A. glabra than other Annona species is presumably due to $A$. glabra being adapted to its native wetland habitat where
$\mathrm{Fe}^{2+}$ is more readily available than in aerated native soils of other Annona species. In fact, A. glabra had significantly lower root ferric chelate reductase activity than $A$. muricata (soursop) seedlings, a commercial species native to drier soils (Fig. 7; Ojeda et al., 2003,

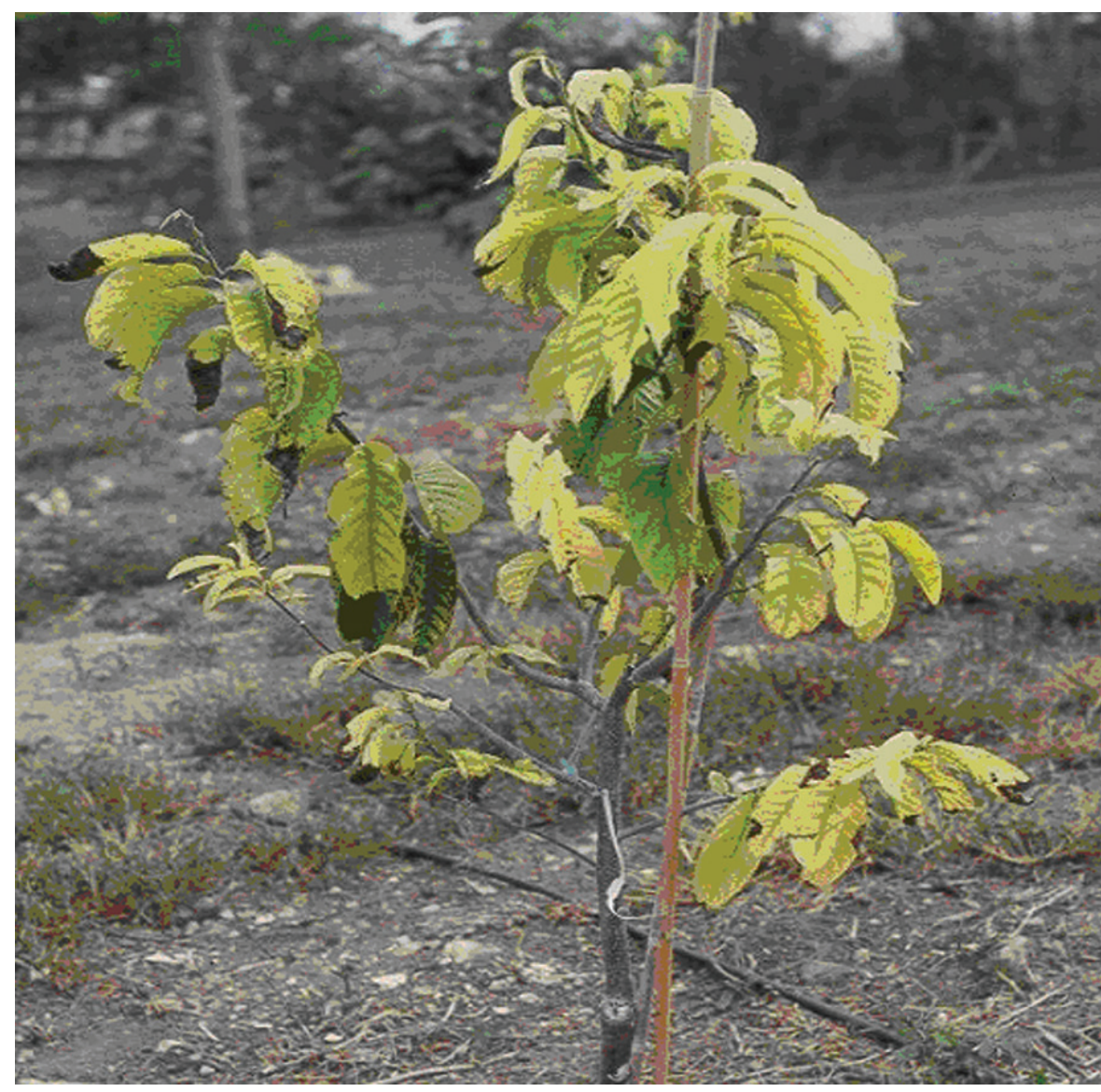

Fig. 5. Annona glabra planted in nonflooded Krome very gravelly loam calcareous soil showing symptoms of iron chlorosis (interveinal chlorosis of leaves).

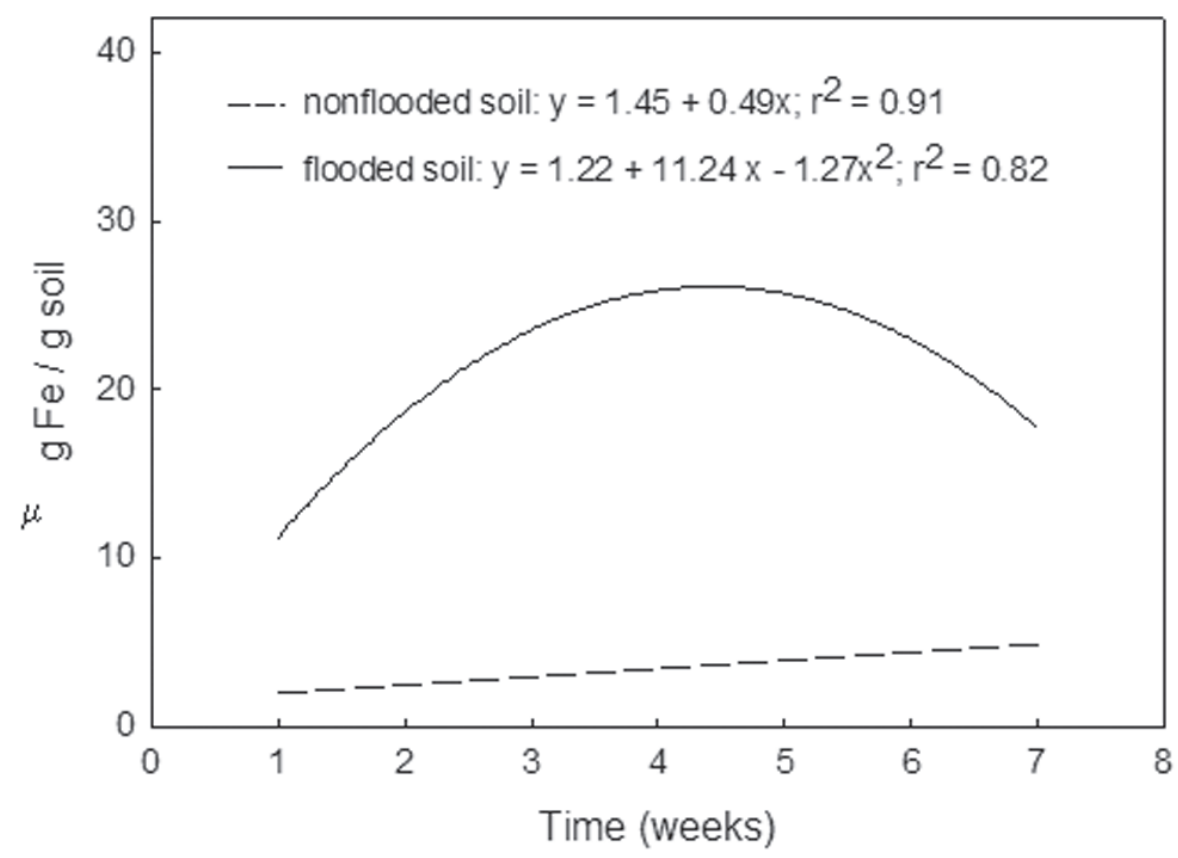

Fig. 6. Concentration of Fe in flooded and nonflooded Krome very gravelly loam calcareous soil over time (adapted from Larson et al., 1991a).
$2004 c)$. Chelated Fe is very expensive to growers (up to $50 \%$ of the total applied chemical cost per orchard). Therefore, if $A$. glabra is to be used as a flood-tolerant rootstock for commercial Annona species in calcareous soils, mechanisms must be identified whereby $A$. glabra can overcome the very high chelated Fe requirement to prevent Fe deficiency, possibly by breeding or molecular approaches to increase FCR activity in this species.

\section{RESPONSES OF CARAMBOLA TO FLOODING}

Carambola, also called star fruit, is adapted to various types of well-drained soils and grows well in a wide range of soil $\mathrm{pH}$ from acid soils $(\mathrm{pH} \sim 4.5)$ to alkaline calcareous soils with a $\mathrm{pH} \sim 7.8$ (Campbell and Malo, 1981; Crane, 1994; Green, 1987). However, carambola trees are more prone to micronutrient deficiency in alkaline calcareous soils than in acid soils (Green, 1987). Thus, similar to annonas and other tropical fruit crops, short-term flooding (a few days) may actually be beneficial to carambola trees due to increased availability of micronutrients in the soil.

Carambola is a moderately flood-tolerant tropical fruit tree species (Crane, 1994; Joyner and Schaffer, 1989). For container-grown carambola trees in acidic (Ismail and Noor, 1996) and alkaline (Joyner and Schaffer, 1989) soils, flooding reduced net $\mathrm{CO}_{2}$ assimilation and stomatal conductance but leaf gas exchange returned to near pre-flood levels when plants were removed from flooded conditions. Continuous flooding of container-grown 'Golden Star' carambola on Golden Star rootstock in alkaline soil for up to 18 weeks resulted in lower net $\mathrm{CO}_{2}$ assimilation, transpiration, stomatal conductance and leaf, stem and root dry weights compared with nonflooded trees (Joyner and Schaffer, 1989). In alkaline soil, carambola trees that were repeatedly flooded for 3 weeks and unflooded for 3 weeks or flooded for 3 weeks and then unflooded for 6 weeks were able to recover from flooding when they were unflooded. $\mathrm{Net} \mathrm{CO}_{2}$ assimilation, transpiration and stomatal conductance returned to near preflood levels and normal shoot and root growth resumed (Joyner and Schaffer, 1989). However, the trees' ability to recover diminished as the number of flooding cycles increased. Also, at the end of several flooding cycles, plant dry weight of cyclically flooded trees was lower than that of nonflooded trees, which was attributed to lower net $\mathrm{CO}_{2}$ assimilation during the flooding period, and the diminished ability for trees to recover from flooding as the number of flooding cycles increased (Joyner and Schaffer, 1989). An interesting observation was that flooded carambola trees had more flowers (Ismail and Noor, 1996; Joyner, 1989; Joyner and Schaffer, 1989) and subsequently more fruit (Joyner, 1989). Thus, in addition to possible micronutrient advantages, shortterm flooding may actually be beneficial to carambola production by stimulating flower and fruit production. 


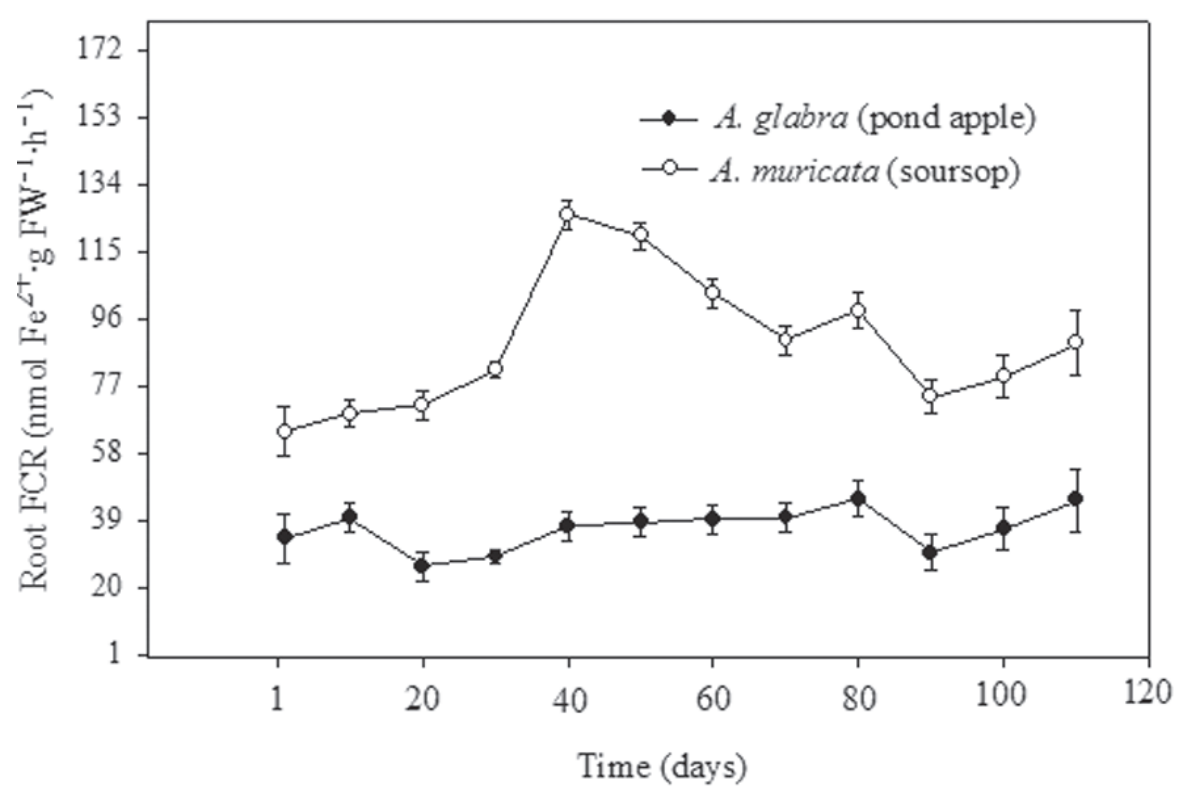

Fig. 7. Ferric chelate reductase (FCR) activity in roots of hydroponically grown pond apple and soursop over time. Plants were grown hydroponically for 19 weeks before FCR determination. Data points represent means \pm SE (adapted from Ojeda et al., 2003).

\section{CONCLUSIONS}

There has been considerable progress in elucidating the relative flood-tolerance of some subtropical and tropical fruit trees in calcareous soil. The early physiological symptoms of prolonged flooding of tropical fruit crops in calcareous soils include decreased net $\mathrm{CO}_{2}$ assimilation, stomatal conductance and transpiration as is typical of most fruit tree species (Rowe and Beardsell, 1973; Schaffer et al., 1992). After a period of continuous flooding, root and shoot growth are inhibited and if trees are not removed from flooding, mortality will occur. There appears to be a range of flood tolerance of subtropical and tropical fruit crops in calcareous soil as determined from leaf gas exchange and plant growth measurements. Avocado trees appear to be relatively sensitive to flooding compared with other species tested, but sensitivity to flooding is greatly exacerbated by phytophthora root rot. Commercial Annona species are also very sensitive to flooding in calcareous soils, whereas mango and carambola trees appear to be moderately flood tolerant. Some tropical fruit species, i.e., carambola (Joyner, 1989; Joyner and Schaffer, 1989) and mango (Larson et al., 1991b) can recover from short-term flooding when removed from a flooded environment. In fact, short-term flooding in alkaline soils may actually be beneficial to subtropical and tropical fruit crops by increasing the availability of micronutrients and reducing $\mathrm{Fe}^{3+}$ to $\mathrm{Fe}^{2+}$, the form metabolized by the plants.

For some tropical and subtropical fruit crops, adaptive morphological and anatomical responses to flooding have been identified. For example responses of some subtropical and tropical fruit trees to flooding include the formation of adventitious roots (Larson et al., 1991b) and/or the development of hypertrophic stem lenticels (Larson et al., 1991b, 1993a, 1993b; Nuñez-Elisea et al., 1999; Ojeda et al., 2004b). These adaptive responses to flooding may be used to screen germplasm for flood tolerance and possibly as criteria for developing flood-tolerant tropical fruit species in the future through conventional breeding or molecular techniques. Additionally, the potential exists for some crops, such as Annona spp., to improve flood tolerance through horticultural techniques such as the use of flood-tolerant rootstocks. For example, flood-tolerance for flood-sensitive Annona species was achieved by grafting them onto A. glabra (pond apple) rootstock, a flood-tolerant, noncommercial Annona species (Nuñez-Elisea et al., 1997, 1998, 1999). However, selecting or developing flood-tolerant subtropical and tropical fruit crops for flood-prone calcareous soils still presents challenges because once flood tolerance is achieved, additional obstacles related to the high soil $\mathrm{pH}$ and micronutrient availability must be overcome.

\section{Literature Cited}

Brown, J.C. 1978. Mechanisms of iron uptake by plants. Plant Cell Environ. 1:249-257.

Campbell, C.W. and S.E. Malo. 1981. The carambola. Fact Sheet FC-12. Univ. Fla. Coop. Ext. Serv., Gainesville.

Chaney, R.L., J.C. Brown, and L.O. Tiffin. 1972. Obligatory reduction of ferric chelates in iron uptake by soybeans. Plant Physiol. 50:208-213.

Crane, J.H. 1994. The carambola (starfruit). Fact Sheet HS-12. Univ. Fla. Inst. Food Agr. Sci., Gainesville.

Crane, J.H. and F.S. Davies. 1989. Flooding responses of Vaccinium species. HortScience 24:203-210.

FAO-AGL. 2004. Food and agricultural organization of the United Nations. FAO-AGL, Land and plant nutrition management service, ProSoil - Problem soils database. Calcareous soils. http://www.fao.org/WAICENT/FaoInfo/Agricult/agl/agll/prosoil/calc.htm. FAO-AGL.

George, A.P., R.J. Nissen, and B.I. Brown. 1987. The custard apple. Queensland Agr. J. $113 \cdot 287-297$.
Green, J.G. 1987. Carambola production in Malaysia and Taiwan. Proc. Fla. State Hort. Soc. 100:275-278.

Ismail, M.R. and K.M. Noor. 1996. Growth and physiological processes of young starfruit (Averrhoa carambola L.) plants under soil flooding. Scientia Hort. 65:229-238.

Iyer, C.P.A. and C. Degani. 1997. Classical breeding and genetics, p. 49-68. In: R.E. Litz (ed.). The mango: Botany, production and uses. CAB Intl. Press, Wallingford, U.K.

Joyner, M.E.B. 1989. Effects of flooding on gas exchange and growth of carambola trees (Averrhoa carambola L.). MS thesis. Univ. Fla. Gainesville.

Joyner, M.E.B. and B. Schaffer. 1989. Flooding of 'Golden Star' carambola trees. Proc. Fla. State Hort. Soc. 102:236-239.

Larson, K.D., D. Graetz, and B. Schaffer. 1991a. Flood-induced chemical transformations in calcareous agricultural soils of South Florida. Soil Sci. 152:33-40.

Larson, K.D., B. Schaffer, and F.S. Davies. 1991b. Flooding, leaf gas exchange and growth of mango in containers. J. Amer. Soc. Hort. Sci. 116:156-160.

Larson, K.D., B. Schaffer, and F.S. Davies. 1991c. Mango responses to flooding in limestone soil. Proc. Fla. State Hort. Soc. 104:33-39.

Larson, K.D., F.S. Davies, and B. Schaffer. 1991d. Floodwater temperature and stem lenticel hypertrophy of Mangifera indica L. Amer. J. Bot. 78:1397-1403.

Larson, K.D., B. Schaffer, F.S. Davies, and C.A Sanchez. 1992. Flooding, mineral nutrition and net gas exchange of mango trees. Scientia Hort. 52:113-124.

Larson, K.D., B. Schaffer, and F.S. Davies. 1993a. Floodwater oxygen content, lenticel hypertrophy, and ethylene evolution from mango trees. J. Expt. Bot. 44:665-671.

Larson, K.D., B. Schaffer, and F.S. Davies. 1993 b. Physiological, morphological, and growth responses of mango trees to flooding. Acta Hort. 341:152-159.

Litz, R.E. and U. Lavi. 1997. Biotechnology, p.401-424. In: R.E. Litz (ed.). The mango: Botany, production and uses. CAB Intl. Press, Wallingford, U.K.

Litz, R.E., Witjaksono, S. Raharho, D. Efendi, F. Pliego-Alfaro, and A. Barceló-Muñoz. 2005. Persea americana Avocado, p. 326-347. In: R.E. Litz (ed.). Biotechnology of fruit and nut crops. CAB Intl. Press, Wallingford, U.K.

Lucena, J. 2000. Effects of bicarbonate, nitrate and other environmental factors on iron deficiency chlorosis. A review. J. Plant Nutr. 23:1591-1601.

Marler, T.E., A.P. George, R.J. Nissen, and P.C. Andersen. 1994. Miscellaneous tropical fruit, p. 199-224. In: B. Schaffer and P.C. Andersen (eds.). Handbook of environmental physiology of fruit crops. vol. 2. Tropical and subtropical crops. CRC Press, Inc., Boca Raton, Fla.

Marschner, H. and V. Römheld. 1994. Strategies of plants for acquisition of iron. Plant Soil 165:261-274.

Martinez, J.A., J.R. Davis, and C.L. Santiago. 1998. Soil survey of the United States Virgin Islands, USDA-NRCS. P. 219.

Mengel, K. 1994. Iron availability in plant tissue-Iron chlorosis on calcareous soils. Plant Soil 165:275-283.

Mengel, K. and G. Geurtzen. 1988. Relationship between iron chlorosis and alkalinity in Zea mays. Physiologia Plant. 72:460-465.

Mengel, K. and E.A. Kirkby. 1982. Principles of plant nutrition. Intl. Potash Inst., WorblaufenBern, Switzerland. 
Nakasoni, H. and R.E. Paull. 1998. Tropical fruit. CAB Intl. Press, Wallingford, U.K.

Noble, C.V., R.W. Drew, and J.D. Slabaugh. 1996. Soil survey of Dade County area Florida. USDA Nat. Res. Cons. Serv., Wash., D.C.

Nuñez-Elisea, R., B. Schaffer, J.Fisher, A.M. Colls, and J.H. Crane. 1999. Influence of flooding on net $\mathrm{CO}_{2}$ assimilation, growth, and stem anatomy of Annona species. Ann. Bot. 74:771-780.

Nuñez-Elisea, R., B. Schaffer, J.H. Crane, and A.M. Colls. 1997. Effects of flooding on growth and leaf gas exchange of Annona species. Proc. First Intl. Congr. Annonaceae, Texcoco, Mexico. p. 124-132.

Nuñez-Elisea, R., B. Schaffer, J.H. Crane, and A.M. Colls. 1998. Leaf gas exchange and growth responses of young, container-grown Annona trees to flooding. HortScience 33:541 (abstr.).

Ojeda, M.G., B. Schaffer, and F.S. Davies. 2003. Ferric chelate reductase activity in roots of two Annona species as affected by iron nutrition. HortScience 38:1104-1107.

Ojeda, M.G., B. Schaffer, and F.S. Davies. 2004a. Iron nutrition, flooding and growth of pond apple (Annona glabra L.). Proc. Fla. State Hort. Soc. 117:210-215.

Ojeda, M.G., B. Schaffer, and F.S. Davies. 2004b. Flooding, root temperature, physiology, and growth of two Annona species. Tree Physiol. 24:1019-1025.

Ojeda, M.G., B. Schaffer, and F.S. Davies. 2004c. Root and leaf ferric chelate reductase activity in pond apple and soursop. J. Plant Nutr. 27:1-13.

Phung, H.T. and E.B. Knipling. 1976. Photosynthesis and transpiration of citrus seedlings under flooded conditions. HortScience 11:131-133.

Ploetz, R.C. and B. Schaffer. 1987. Effects of flooding and phytophthora root rot on photosynthetic characteristics of avocado. Proc. Fla. State Hort.
Soc. 100:290-294.

Ploetz, R.C. and B. Schaffer. 1989. Effects of flooding and phytophthora root rot on net gas exchange and growth of avocado. Phytopathology 79:204-208.

Ploetz, R.C, R. Schnell, and J.L. Haynes. 2002. Variable response of open-pollinated seedings progeny of avocado to phytophthora root rot. Phytoparasitica 30:262-268.

Ponnamperuma, F.N.1972. The chemistry of submerged sols. Adv. Agron. 24:29-96.

Ponnamperuma, F.N. 1984. Effects of flooding on soils, p. 9-45. In: Flooding and plant growth. T. T. Kozlowski (ed.). Academic Press, Orlando, Fla..

Popenoe, W. 1974. Manual of tropical and subtropical fruit. Hafner Press, New York.

Rowe, R.N. and D.V. Beardsell. 1973. Waterlogging of fruit trees. Hort. Abstr. 43:534-544.

Samson, J.A. 1980. Tropical fruit. Longman Scientific and Technical, Essex, U.K., and John Wiley and Sons, Inc., NY.

Schaffer, B. 1998. Flooding responses and water-use efficiency of subtropical and tropical fruit trees in an environmentally-sensitive wetland. Ann. Bot. 81:475-481.

Schaffer, B. 1991. Flood tolerance of Tahiti lime rootstocks in south Florida soil. Proc. Fla. State Hort. Soc. 104:31-32.

Schaffer, B., P.C. Andersen, and R.C. Ploetz. 1992. Responses of fruit crops to flooding, p. 257-313. In. J. Janick (ed.). Horticultural reviews. vol. 13. Wiley, New York.

Schaffer, B. and P.A. Moon. 1990. Influence of rootstock on flood tolerance of Tahiti lime trees. Proc. Fla. State Hort. Soc. 103:318-321.

Schaffer, B. and R.C. Ploetz. 1989. Gas exchange characteristics as indicators of damage thresholds for phytophthora root rot of flooded and nonflooded avocado trees. HortScience
24:653-655.

Schaffer, B. and A.W. Whiley. 2002. Environmental physiology of avocado, p. 135-160. In: A.W. Whiley, B. Schaffer, and B.N. Wolstenholme (eds.). Avocado: Botany, production and uses. CAB Intl. Press, Wallingford, U.K.

Schaffer, B. and A. W. Whiley. 2003. Environmental regulation of photosynthesis - A mini-review. Proc. 5th World Avocado Congr. vol. 1. p. 335-342.

Schaffer, B., A.W. Whiley, and J.H. Crane. 1994. Mango, p. 165-197. In: B. Schaffer and P.C. Andersen (eds.). Environmental physiology of fruit crops. vol. 2. Sub-tropical and tropical crops. CRC Press, Boca Raton, Fla.

Syvertsen, J.P., R.M. Zablotowicz, and M.L. Smith. 1983. Soil temperature and flooding affects two species of citrus. I. Plant growth and hydraulic conductivity. Plant Soil 72:3-12.

USDA-NRCS. 2004. Caribbean area online soil survey manuscripts. USDA-NRCS. http://soils. usda.gov/survey/online_surveys/caribbean.

Witjaksono. 1997. Development of protocols for avocado tissue culture: Somatic embryogenesis, protoplast culture, shoot proliferation and protoplast fusion. $\mathrm{PhD}$ thesis. Univ. Fla., Gainesville.

Whiley, A.W. and B. Schaffer. 1994. Avocado, p. 3-36. In: B. Schaffer and P.C. Andersen (eds.). Environmental physiology of fruit crops. vol. 2. Sub-tropical and tropical crops. CRC Press, Boca Raton, Fla.

Whiley, A.W. and B. Schaffer. 1997. Stress physiology, p. 147-173. In: R.E. Litz (ed.). The mango: Botany, production and uses. CAB Intl. Press, Wallingford, U.K.

Zotz, G., M.T. Tyree, and S. Patino. 1997. Hydraulic architecture and water relations of a flood tolerant tropical tree, Annona glabra. Tree Physiol. 17:359-365. 